\title{
Feeding and reproductive behaviour of pigeon slender louse, Columbicola columbae (Phthiraptera, Insecta, Ischnocera)
}

\author{
Suneel Kumar Singh*, Surman Arya ${ }^{1}$, Sanjay Kumar Singh² and Vikram Khan ${ }^{3}$ \\ Department of Biotechnology, Modern Institute of Technology, Dhalwala, Rishikesh-249201(Uttarakhand), INDIA \\ ${ }^{1}$ Department of Zoology, Govt. P.G. College, Gopeshwar, (Uttarakhand), INDIA \\ ${ }^{2}$ Department of Zoology, T.D. (P.G.) College, Chakke, Jaunpur (U.P.), INDIA \\ ${ }^{3}$ Department of Zoology, Govt. P.G. College, Rampur (U.P.), INDIA \\ *Corresponding author. E-mail: drsuneelkumarsingh@gmail.com
}

\begin{abstract}
Columbicola columbae, the pigeon slender louse mostly feeds upon the barbules of feathers but in addition to this it also feeds upon skin scurf, epidermal scales, sheaths of growing feathers, pellicle of skin etc. $C$. columbae is exclusively keratin feeder and does not take host blood. Any sex or stage related difference in feeding habit has not been recorded. It neither harbours any triturating agent in the crop nor is involved in cannibalism or predation. C. columbae exhibits sub-feminal mating behaviour (i.e., the male is under the female). Complete copulation lasts about 10 hours. The louse prefers the wing and tail feathers for oviposition. The eggs are generally laid on the ventral surface of the first row of undercoverts of wing feathers. Every event that takes place prior to eclosion of nymph, the time required for detachment of operculum and the freeing of nymph has been noted during hatching.
\end{abstract}

Keywords: Phthiraptera, Pigeon louse, Columbicola columbae, Feeding, Reproductive behaviour

\section{INTRODUCTION}

Mallophaga exhibits considerable diversity with respect to feeding, mating, oviposition and hatching behaviour. Feeding habits of selected lice species has been demonstrated by phthirapterologists from time to time (Wilson, 1933; Martin, 1934; Eichler, 1939; Crutchfield and Hixon, 1943; Bouvier, 1945; Dubinin, 1947; Clay, 1949; Rothschild and Clay, 1952; Arora and Chopra, 1959; Blagovestchesnky, 1959; Ash, 1960; Kalamarz, 1963; Brown, 1970; Askew, 1971; Nelson, 1971; Nelson and Murray, 1971; Derylo, 1975; Seager et al., 1976; Agarwal and Saxena,1978 and 1980; Agarwalet al., 1982 and 1983; Saxena et al., 1985; Trivedi et al., 1990). Many species feed upon feather derivatives (barbs, barbules, sheaths of growing feather) along with the pellicle of skin and sheaths of growing feathers. Certain species consume host blood (in variable amount) along with feather derivatives; while others are exclusively haematophagous (and fail to survive in absence of host blood. Secretions of skin, mucus and secretions of sebaceous gland) also act as a part of diet of few species. The information about the position of sexes during mating is unavailable in the literature, though the life history of few phthirapteran species has become available (Crystal, 1949; Bair, 1950; Conci, 1952, 56a and b; Scott, 1952; Waterhouse, 1953; Schmutz, 1955; Stenram, 1956; Arora and Chopra, 1959; Murray, 1957a, 1957b, 1957c and 1957d; Agarwal, 1967; Agarwal and Saxena, 1982a and b; Saxena et al., 1993; Surman et al., 1998 and Singh et al., 2001). According to Sikora and Eichler (1941); Eichler (1963); Schmutz (1955) and Oniki (1999), in most cases (especially in ischnoceran species the position is subfeminal (i.e., the male is under the female). In such case, male clasps the first abdominal segment of the female from below with his seizing antennae.

Limited information is available on egg laying (oviposition) behaviour of mallophagan species as Richter (1870), Snodgrass (1899), Pfleger (1929), Martin (1934), Wilson (1933 and 1939), Clay and Rothschild (1938), Eichler (1950 and 1963), Blagovestchensky (1955 and 1959), Stockdale and Raun (1965), Agarwal (1967), Foster (1969), Williams (1970), Agarwal and Saxena (1982a and 1982b), Saxena et al. (1991, 1993 and 1994), Surman et al. (1998), Saxena et al. (2000), Kumar et al. (2006) and Gupta et al. (2008) have provided information on the oviposition sites, pattern of egg laying, pasture adopted during egg laying and structure of eggs of some avian Phthiraptera.

Very few workers have studied the hatching behaviour of the avian lice (Wigglesworth, 1932; Eichler, 1963, Agarwal, 1959 and 67, Trivedi et al., 1992). Kumar and Somadder (1974) have given an account of hatching 
organ of three anopluran species. Kumar et al. (1996) has performed the work on hatching behaviour of a mammalian louse, Bovicola coprae. Hatching behavior shows the pattern of eclosion of the nymph from the egg and the duration of entire process. In the present studies an attempt was made to study the hatching behavior of Pigeon slender louse $C$. columbae as being sluggish it was found to handle easily.

\section{MATERIALS AND METHODS}

A. Feeding behaviour: The live lice (Columbicola columbae) were collected from infested pigeons. These were dissected under stereozoom dissecting trinocular microscope to observe their feeding behaviour. The crop was taken out, dehydrated, stained, and teased out with the help of fine needles at clove oil stage and examined under microscope. Attempts were also made to record the feeding habits of lice by direct examination with the help of magnifying torch.

B. Mating behaviour: Ten pairs of unknown age fresh looking healthier adults (both the sexes) of C. columbae were sorted out from host bird/culture stock and colonized in glass petri dishes with bottom lined with black paper. A layer of suitably chopped feathers was laid at the bottom, to facilitate the lice, which habitually fell down while running over the feathers. The feathers plucked from fore parts of body (side, vent and back) were provided as food, as C. columbae prefer to feed on fluffy zone of body feathers. The events of paring was observed by placing the petri dishes under trinocular dissecting microscope.

C. Egg laying sites: The egg laying sites of C. columbae were studied in the temporary anaesthetized infested pigeons. They were placed in polythene bags along with a wad of cotton soaked in chloroform with the head outside the bag. Host body was demarcated into nine regions (viz., head, nape, neck, back, breast, abdomen, wings, legs, and tail) based on the scaling pattern. Feathers of each region were examined with the help of magnifying lens and torch. Posture adopted by female during egg laying was also observed with the magnifying torch.

D. Hatching behaviour: Freshly laid eggs of $C$. columbae, were sorted out with the help of binocular microscope. The eggs then glued to glass slide along with the trimmed hair. The eggs were incubated at $35 \pm 1^{\circ} \mathrm{C}$ and $75 \% \mathrm{RH}$ for 6-7 days. Thereafter, they were kept under constant observation under stereozoom binocular microscope. The events of hatching were observed critically and recorded simultaneously

\section{RESULTS}

Columbicola columbae is observed to be present throughout the year on pigeons. It is usually found clinging or slowly moving over covered basal portion of feathers of wings, neck and breast feathers harbour adults for egg laying. They are also found sunckened in the quills of down feathers of breast. During the high infestation state they occupy practically all the feathers of the body. The variations in the population, and their abundance on different areas over the body of pigeon, during different seasons of the year has, already been studied by Singh et al. (2000).

The feeding behavior in lice showed that the lice, preparatory to feed, hold the feather with the help of meso and meta-thoracic legs and uses prothoracic legs to hold a single feather barbules or barb, which is pushed into the oral cavity by the downward and backward movements of pulvinus. Maxillae also help in getting the barbules in the oral cavity, while the sharp edged mandibles cut the barbules into pieces, which are finally forced inside the mouth by labrum. It was observed that the pieces of barbules, which are found in the crop, are of uniform size. These pieces of barbules, taken one after the other, are passed into the crop through pharynx and oesophagus to get arranged in lengthwise manner. The antero-dorsal wall of the crop of $C$. columbae internally bears 25-35 groups of cropteeth (Fig. 1A and B), attached to crop wall (measuring 120-180 ìm in length and 30-70 ìm in width in area) with their broad bases while pointed end hanging freely in crop lumen. The number of teeth varies from 4 to 10 in each group and the size of teeth ranges from 2.5 to 5.1 ìm in length and 1 to 2 ìm in width, at the bases. The crop teeth presumably play role in trituration of feather barbules when the latter are rubbed against teeth during regular peristaltic movements of crop (Fig. 1A and B). The crop, which is pear or tadpole-shaped blind sac, being elastic in nature is able to accommodate plenty of such pieces of feather barbules. Furthermore, the crop undergoes regular anti-peristaltic movements arising at its posterior end, followed by the peristaltic movements in opposite direction due to which the tips of barbules are rubbed against the groups of crop teeth present at the anterior end of crop wall. The examination of the crop contents reveals that the lice mostly feed upon the barbules of feather but in addition to this, pellicle of skin, sheaths of growing feathers, scurfs and epidermal scales are also detected in the crop. Further in some cases the traces of the coagulated blood of the host are also seen along with the feather food.

The lice copulate only after 72-80 hours of the final moult, after they have undergone complete hardening and darkening. Normally copulation takes place during late evening and the night. Males and females isolated from each other for a day or two readily copulate when placed together. During the initial stages of copulation; the male approaches the female on one side, pushes the anterior end of its body beneath that of the female and finally 
Table 1. The sequence of events that took place during hatching of an embryo of pigeon slender louse, Columbicola columbae.

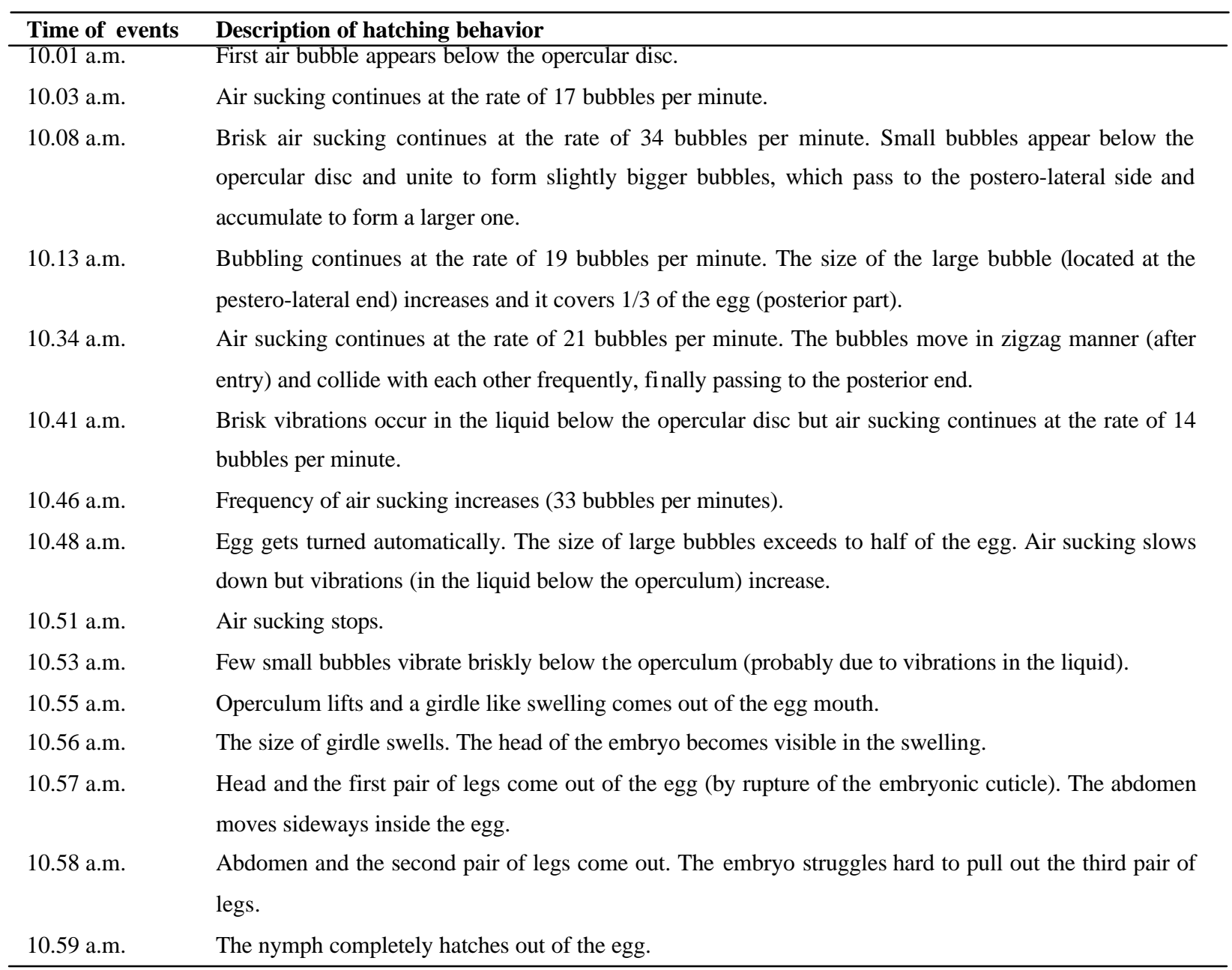

draw its abdomen in such a way that the entire body of the female comes to lie on top of the male (Fig. 2 A to D). The male then quickly flexes its antennae upwards and firmly grips the trochanters of the third legs of the female by the hook-like process on the third antennal segment. This process is pressed against the trochanter of the third leg of its side of the female and the third and fourth antennal segments remain free; the small projection on the dorsal side of the first antennal segment acts as a buttress against the leg. At the same time, it curls the abdomen upwards and extends it forwards till the abdominal extremity is brought into contact with the ventro-terminal part of the female abdomen. It then jerks the abdominal extremity several times so that the vulva of the female is opened and then inserts its genitalia into the female genital chamber. Thus, the process of copulation starts (Fig. 2A to D). Copulation usually lasts from few minutes to 10 hours but in a few instances it continued even longer. Occasionally copulating pairs separate within an hour, possibly due to some disturbance, but copulate again within a few minutes or hours. The female undergoes copulation several times during its lifespan and is ready for mating as early as an hour after egg laying.

Most common oviposition site of Columbicola columbae remained the wing feathers, which contained $77 \%$ of the total number of eggs. Tail feathers carried $15 \%$ eggs, while $4 \%$ occurred on abdominal feathers. Egg count on other areas of body remained nil to negligible (>1\%). The eggs are generally laid on ventral surface of the first row of under coverts of wing feathers (in furrows between the barbs with operculum towards vane) (Figure $3 \mathrm{~A}$ and $\mathrm{B}$ ). Prior to egg laying, the female crawls on a feather, close to the rachis. The female lowers the posterior portion of her abdomen, and then exhibits abdominal contractions (at first contractions are from side to side then the tip of abdomen contracts in and out). It exudes a thick transparent gelatinous substance from the genital opening and raises the abdomen $4-5$ times, before passing the egg. Within 10-15 seconds of secretion, the egg passes out implanted in already exuded secretion. After egg laying, the female remains quite for nearly 25 seconds and then moves away. The eggs are glued with the cementing material on the feathers belonging to different 
Table 2: Duration of different stages during hatching of 5 nymphs of pigeon slender louse, Columbicola columbae.

\begin{tabular}{|c|c|c|c|}
\hline \multirow[t]{2}{*}{ S. No. } & \multicolumn{2}{|c|}{ Time required for } & \multirow[b]{2}{*}{$\begin{array}{c}\text { Complete } \\
\text { process }\end{array}$} \\
\hline & $\begin{array}{l}\text { Detaching of the } \\
\text { operculum }\end{array}$ & $\begin{array}{l}\text { Freeing from } \\
\text { the egg }\end{array}$ & \\
\hline Nymph 1 & 50 minutes & $\begin{array}{l}2 \text { minutes } \\
34 \text { seconds }\end{array}$ & $\begin{array}{l}52 \text { minutes } \\
34 \text { seconds }\end{array}$ \\
\hline Nymph 2 & 51 minutes & $\begin{array}{l}2 \text { minutes } \\
30 \text { seconds }\end{array}$ & $\begin{array}{l}53 \text { minutes } \\
30 \text { seconds }\end{array}$ \\
\hline Nymph 3 & 48 minutes & $\begin{array}{l}3 \text { minutes } \\
12 \text { seconds }\end{array}$ & $\begin{array}{l}51 \text { minutes } \\
12 \text { seconds }\end{array}$ \\
\hline Nymph 4 & 44 minutes & $\begin{array}{l}2 \text { minutes } \\
50 \text { seconds }\end{array}$ & $\begin{array}{l}46 \text { minutes } \\
50 \text { seconds }\end{array}$ \\
\hline Nymph 5 & 49 minutes & $\begin{array}{l}3 \text { minutes } \\
20 \text { seconds }\end{array}$ & $\begin{array}{l}52 \text { minutes } \\
20 \text { seconds }\end{array}$ \\
\hline Average & $\begin{array}{l}48 \text { minutes } \\
40 \text { seconds }\end{array}$ & $\begin{array}{l}2 \text { minutes } \\
53 \text { seconds }\end{array}$ & $\begin{array}{l}51 \text { minutes } \\
29 \text { seconds }\end{array}$ \\
\hline
\end{tabular}

body parts of the hosts. The species shows definite pattern of egg laying.

The embryo starts sucking air at least one hour before the hatching. The sequences of events that follow the entry of air bubbles have listed in Table - 1. The time required for the detachment of the operculum and freeing of nymphs from five eggs of $C$. columbae have been indicated in Table 2. The air bubbles suck by the embryos make a large bubble at the posterior side of egg. The pressure caused by continuously increasing air bubbles ultimately causes the detachment of operculum (Fig. 4A to $\mathrm{E}$ ). The role played by hatching organ (and also the hatching spines, present on the disc) remains obscured during direct observation (under stereozoom binocular microscope). After the detachment, a girdle-like swelling (embryonic cuticle filled with air), containing the head of embryo comes out of the egg. The increased pressure from the inner side leads to the splitting of cuticle. The head as well as first pair of legs become free followed by

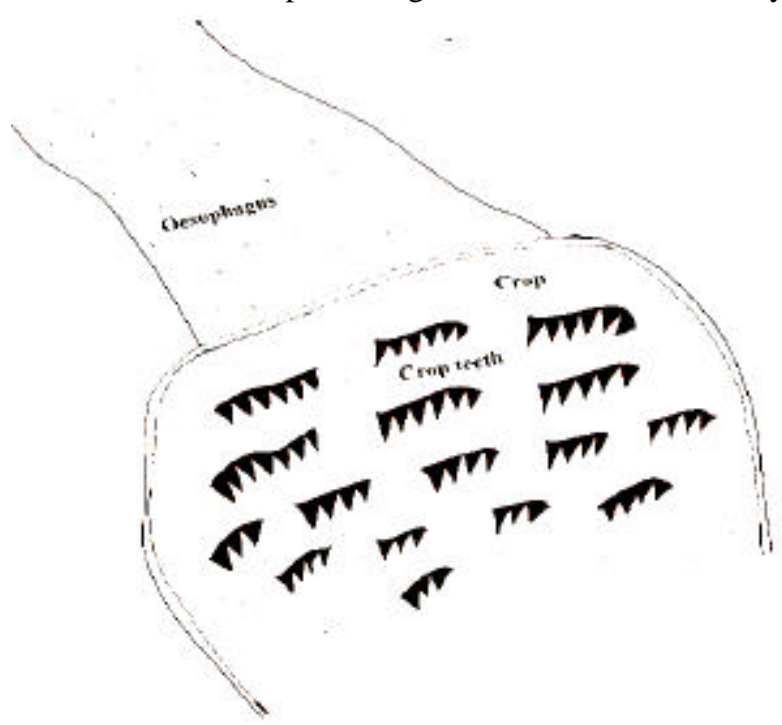

Fig.1. (A) Diagramatic presentation of the crop teeth in the anterior dorsal wall of crop of Columbicola columbae. sideways movement of the abdomen inside the egg (Fig. $4 \mathrm{~A}$ to $\mathrm{E}$ ). Soon the abdomen and the remaining pair of legs come out mainly due to embryo effort. The average time required for detachment of operculum and for emergence of embryo was found to be 48 minutes and 40 seconds; and 2 minutes and 53 seconds; respectively. The entire process lasts 51 minutes and 29 seconds (Table 2).

\section{DISCUSSION}

There is much controversy regarding the feeding habits of Mallophaga. Apart from regular feather diet, many of them, specially, amblyceran species take the blood of their host. The feeding habits of Columbicola columbae, resemble to some extent with that of Lipeurus lawrensis tropicalis, L. caponis, L. tropicalis, Goniodes gigas, and G. hologaster, which usually take feather barbs, barbules sometime skin scuff, epidermal scale, sheaths of growing feathers, pellicle of skin and occasionally the coagulated blood (Crutchfield and Hixon, 1943; Arora and Chopra,

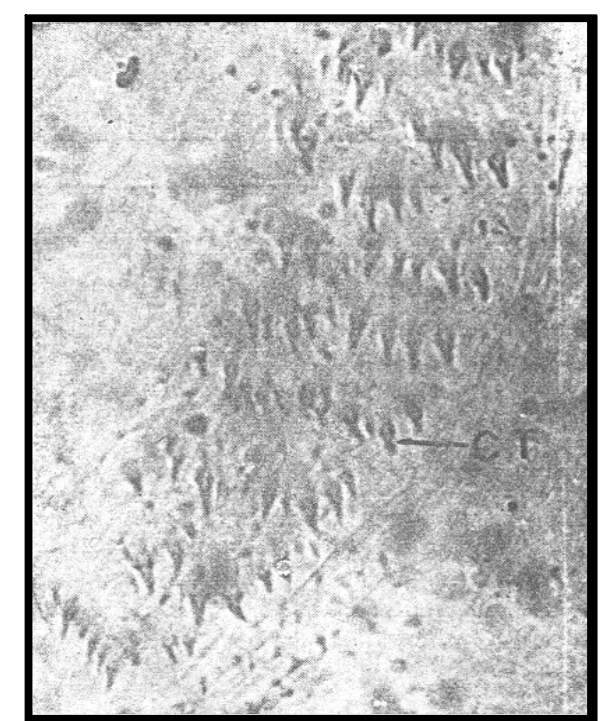

Fig. 1. (B) Showing some parts of the crop teeth of Columbicola columbae under dissecting microscope. 

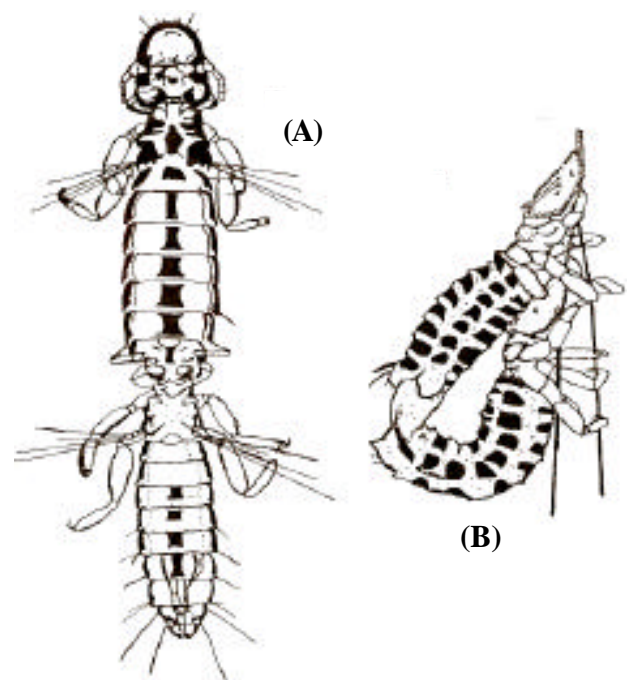

(B)

Fig. 2. (A and B) Showing mating behavior of pigeon slender louse, Columbicola columbae.

1959; Agarwal and Saxena, 1978 and 80). However, the ischnoceran louse species mostly do not take blood meal (Kalamarz, 1963). Furthermore, ischnocerans neither ingests any triturating agent like granules of quartz, mica, sand, grain, seed coat, fungus spore and cuticular processes as reported in case of Esthiopterum monile infesting vulture (Waterston, 1926), nor is involved in cannibalism as no egg shell is found in its crop contents. Blagovestchensky (1959) reported the presence of egg cases, cast skins and body parts of lice and mites in the gut of lice and Nelson (1971) reported, as many as $80 \%$ nymphs of one generation of Colpocephalum turbinatum, infesting pigeon, were eaten up by their adults in vitro. He further added that they consume entire egg except cemented portion along with nymphs while chorions of hatched eggs and marked dead nymphs and cast skins were not preferred. Moreover, very heavy infestation of haematophagic species may cause considerable skin injury and ultimate death of host. Zlotorzycka and Danecki (1969) have reported the death of host (Limmergeier) due to Laemobothrion vultures
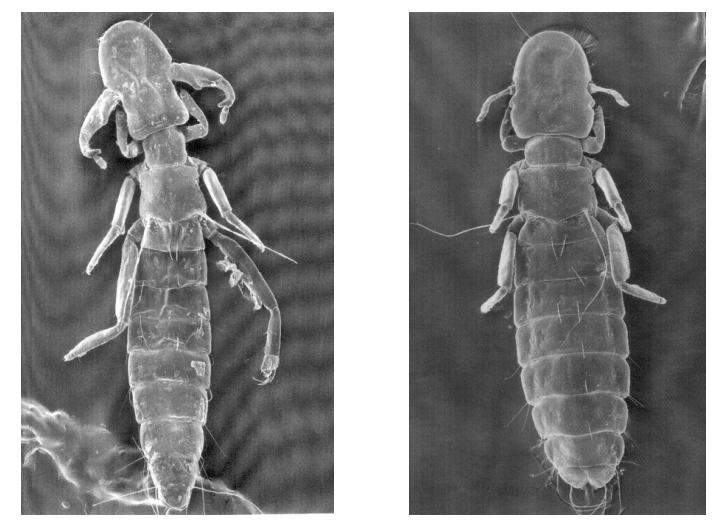

Fig. 2(C and D) Male and female Columbicola columbae.

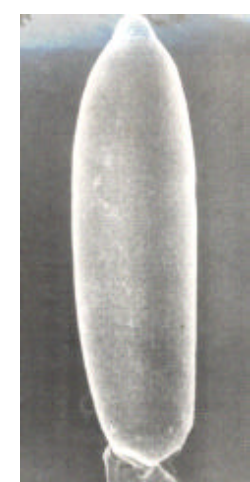

Fig. 3. (A) Egg of Columbicola columbae.

danecki and the cases of hemorrhagic ulcerative stomatitis leading to death of host (while pelican) due to heavy infestation of Piagetiella sp. have been shown by Wobesser et al. (1974). The lesions made by such species may cause significant blood loss and may provide a potential site for entry of other pathogens. The present reports suggest that the attention should be paid to those mallophagan species having a tendency to obtain host blood occasionally or regularly by studing their feeding behaviour. Such species not only affect the vitality and health of host but are also able to act as transmitter of pathogens of various diseases and as intermediate host of helminthes and nematodes.

Mallophaga are known to be dependent on lower or higher temperature (Surman et al., 1998 and Saxena et al., 2004), but Urban and Zlotorzycka (1981) have shown that some may survive low temperatures for a relatively long period. The fact that ten pairs of Columbicola columbae were in copulatory position suggests that copulation could have been a reaction to the approaching danger of freezing. The copulating Menopon gallinae, Gliricola porcelli and Trimenopon hispidium lie belly to belly, which Schmutz (1955) describes as "variant of supra-feminal copulation" while Neocolpocephalum

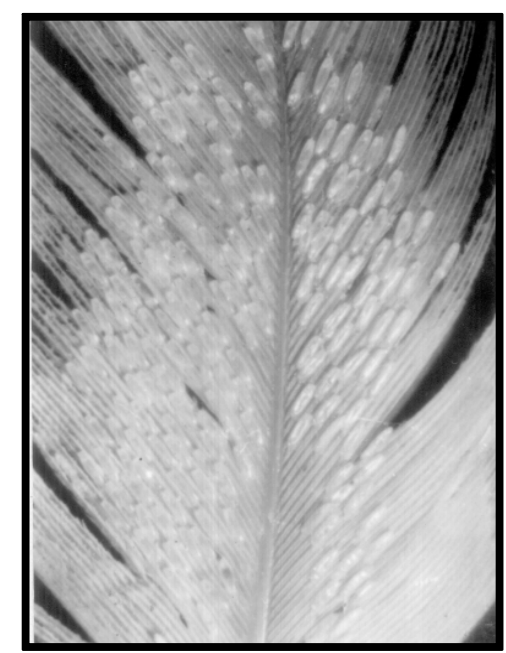

Fig. 3. (B) Oviposition site of Columbicola columbae. 


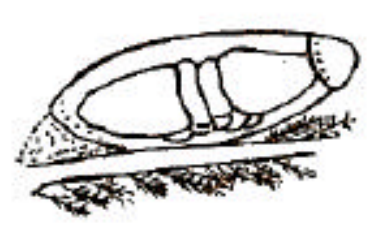

(A)

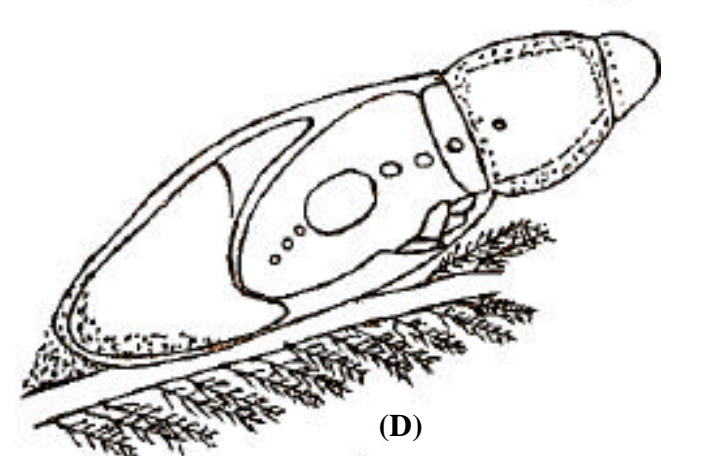

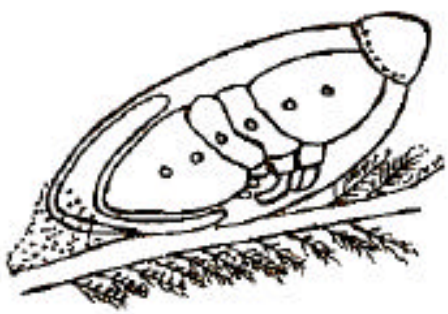

(B)

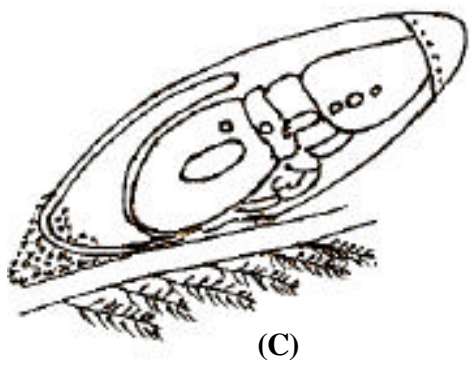

(C)

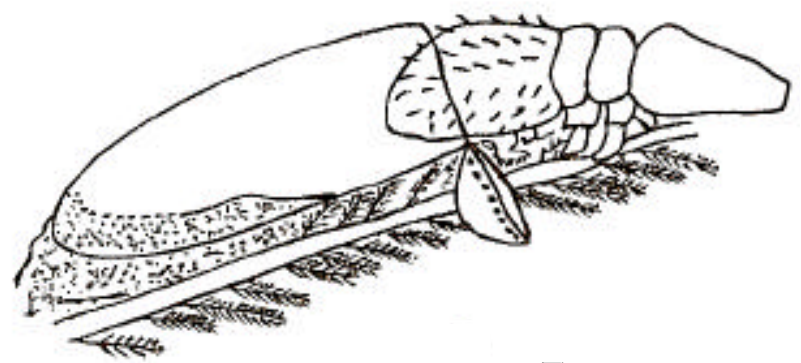

(E)

Fig. 4. (A to E) Diagrammatic representation of events (A to E) during hatching of the nymph of pigeon louse, Columbicola columbae.

copulates with the tips of the dorsum together, but the heads turned away. In case of Culicula latirostris, the two animals lie side by side in the form of a ' $\mathrm{V}$ ' shape and the male pushes the end of its dorsum below that of the female. The duration of the copulation of Mallophaga fluctuates between a few minutes to 2 days. InIbiodoecus plataleae, it takes 40 hours and Pfleger (1929) has noted up to 34 hours. Schmutz (1955) found to 10-15 minutes for Trimenopon hispidium and 10-15 seconds for Bovicola caprae. Such a short time is made possible by the rapid ejaculation of semen as a result of the powerful suction pump. Lice are the only oviparous ectoparasites (except a single flea species), which deposit the eggs and adhere them to the body of the host (Marshall, 1981). Contrary to the general belief that egg of all the mallophagan species is glued to the feathers of the feathers of the host. $C$. columbae lays its eggs on the ventral surface of the first row of under coverts of wing feather (in furrows between the barbs with operculum towards vane. Avian lice reportedly exhibit certain protective features with respect to oviposition sites. Most of lice species tend to lay eggs on specific areas of host body (Ash, 1960). The amblyceran lice (e.g., Colpocephalem turbinatum, Hohorstiella lata, Menopon gallinae, Menacanthus eurysternus, Myrsidea sp. etc) normally prefer head and neck region (Nelson and Murray, 1971; Nelson, 1971; Surman et al. 1998; Singh et al., 2000 \& Kumar et al., 2006). The eggs of $C$. columbae also exhibited the similar sites of oviposition. Most of the ischnoceran lice prefers site like the wings, back and barbs feathers (Agarwal, 1959; Martin, 1934, Agarwal, 1967; Marshall, 1981). The present studies that $C$. columbae prefers wings, back and barbs feathers, further support to the findings of
Eichler (1963), Nelson and Murray (1971), Brown (1970), Surman et al. (1998), Singh (1999), Singh et al. (2000), Saxena et al. (2000) and Gupta et al. (2008). The report on the egg laying behaviour of pigeon slender louse, $C$. columbae fills the lacuna in aspects of oviposition sites as well as egg laying behaviour.

Information on the hatching behaviour of mallophagans is available from the work of Wigglesworth (1932), Martin (1934), Arora and Chopra (1959), Eichler (1963) and Agarwal and Saxena (1982a and b). Agarwal (1967) made most valuable contribution on the hatching behaviour of Falcolipeurus frater (infesting vultures) and Trivedi et al. (1992) furnished information on same aspect of two phthirapterans, Lipeurus lawrensis tropicalis and Menopon gallinae (infesting poultry birds). Any remarkable deviation from the available description has not been recorded in case of C. columbae.

In present study, the pattern of hatching period of Pigeon slender louse, C. columbae, has been found similar to that ofother louse. In case of $F$. frater, egg requires 1 hour 2 minutes to 1 hour 40 minutes for detaching the operculum, $13-15$ minutes for freeing from egg and the complete process lasts 1 hour 15 minutes to 1 hour 55 minutes (Agarwal 1967). In case of L. lawrensis tropicalis the process last 2 hours 10 minutes to 2 hours 16 minutes (average 2 hours 4 minutes for detachment of operculum and 9 minutes for freeing from egg). On the other hand, in case of M. gallinae the entire process takes an average of 44 minutes (42 minutes for detachment of operculum and 2 minutes for freeing from egg).

\section{ACKNOWLEDGEMENTS}

Authors are thankful to Director, Modern Institute of 
Technology, Dhalwala, Rishikesh and Principal, Kutir (P.G.) College, Chakke, Jaunpur (U.P.) for providing laboratory and computer facilities; to Dr. Vincent S. Smith (Cyber Taxonomist, U.K.) and Prof. E. Mey (Rudolstadt, Germany) for valuable help in identification of lice species.

\section{REFERENCES}

Agarwal, G.P. (1959). Studies on the bionomics and life-history of some of the mallophagan parasites of Indian birds. Ph.D. Thesis, Lucknow University, Lucknow (India).

Agarwal, G.P. (1967). Studies on the bionomics and life-history of Falcolipeurus frater (Gieble: 1874) (Mallophaga: Ischnocera). Ind. J. Zootomy, 8, 21-40.

Agarwal, G.P. and Saxena, A. K. (1978). The cropteeth and spines of the crop of Lipeurus lawrensis tropicalis, Peters (Phthiraptera: Ischnocera). Ind. J. Parasitol., 2, 27-28.

Agarwal, G.P. and Saxena, A.K. (1980). Feeding behaviour of Lipeurus lawrensis tropicalis Peters (Phthiraptera: Ischnocera) infesting poultry birds. Z. ang. Entomol., 89(5), 425-427.

Agarwal, G.P. and Saxena, A.K. (1982a). Oviposition in Lipeurus lawrensis tropicalis Peters, an ischnoceran Phthiraptera. Zool. Mag., 31, 18-22.

Agarwal, G.P. and Saxena, A.K. (1982b). Hatching organ of Lipeurus lawrensis tropicalis Peters (Phthiraptera: Ischnocera). Rivista di Parassitol., 33(1), 63-66.

Agarwal, G.P., Chandra, S. and Saxena, A.K. (1982). Feeding habits of dog ouse, Heterodoxus spiniger (End.) (Mallophaga: Amblycera). Z. Ang. Entomol., 94(2), 134-137.

Agarwal, G.P., Saxena, A.K. and Chandra, S. (1983). Haematophagous behaviour of Menacanthus eurysternus (Mallophaga, Amblycera). Angew. Parasitol., 24, 55-59.

Arora, G.L. and Chopra, N.P. (1959). Observations on the life history of Lipeurus lawrensis tropicalis Peters (Mallophaga: Ischneccera). Res. Bull. Panjab Univ. Sci. (N.S.), 10(11), 179-187.

Askew, R.R. (1971). Parasitic insects. London (Heineman Educational Books).

Ash, J.S. (1960). A study of the Mallophaga of birds with particular reference to their ecology. Ibis, 102 (1), 93-110.

Bair, T.D. (1950).Experimental determination of the autoselected temperature in the chicken louse, Cuclotogaster heterographus (Nitzsch). Ecology, 31(3), 474-477.

Blagovestchensky, D.I. (1955). K morfologii yajca puchoedov (Mallophaga). Trudy Zool. Inst. Akad. Nauk SSSR (Leningrad), 21. 262-270.

Blagovestchensky, D.I. (1959). Nasekomye puchoedy Tom I, vyp. 1- Fauna SSSR (Moskva-Leningrad). n.s. 72.

Bouvier, G. (1945). De'l haemophagie de quelques Mallophages des animaux domestques. Schqeiz. Arch Tierheilk.,87,429-434.

Brown, N.S. (1970). Distribution of Menacanthus stramineus in relation to chicken's surface temperature. J. Parasitol., $56,1205$.

Clay, T. (1949). Piercing mouth-parts in the biting lice (Mallophaga). Nature, 164, 617.

Clay, T. and Rothschild, M. (1938). Ectoparasites from captive birds. I. 1936-1937. Novit. Zool. (Tring)., 41, 61-73.

Conci, C. (1952). L allevamento in condizioni sperimentali dei Mallofagil. Cuclotogaster heterographus Nitzsch. Boll.
Mus. ${ }^{\text {st }}$ Biol. Univ. Genova, 24, 17-40.

Conci, C. (1956a). L allevamento in condizione sperimentali dei Mallofagi II, Stenocrotaphus gigas (Taschenberg). Mem. Soc. Entomol. Ital., 35, 133-150.

Conci, C. (1956b). L allevamento in condizione sperimentali dei Mallofagi III. Columbicola c.columbae (Linnaeus, 1758). Boll. Mus. $1^{\text {st }}$ Biol. Univ. Genova, 26, 47-70.

Crutchfield, M. and Hixon, H. (1943). Food habits of several species of poultry lice with species reference to blood consumption. Florida Entomol., 26, 63-66.

Crystal, M.M. (1949). A descriptive of the life history stages of the dog biting louse, Trichodectes canis (DeGeer) (Mallophaga: Trichodectidae). Bull. Brooklyn Entomol. Soc. (Brooklyn), 44, 89-97.

Derylo, A. (1975). Badania nad szkodliwoscia gospodarcza wszolow (Mallophaga). V. proba ustalenia roli wszolow Eomenacanthus stramineus (Nitzsch). W przenoszeniutyfusu u kur. Wiad. Parazytol., 21, 61-68.

Dubinin, W.B. (1947). Studies on the adaptations of ectoparasites : Ecological adaptation of the mallophagan and feather ticks. Parazytol. Sborn., 9, 191-222.

Eichler, W. (1939). Topographische spezialisation bei ektoparasiten. Zeit. Fur. Parasit., 11, 205-214.

Eichler, W. (1950). Federlingseir an und in Vogelfedern. Dtzsch. Entomol., 40, 41-61.

Eichler, W. (1963). In: Dr. H. G. Bronns Klassen und ordnungen des Tierreichs (b) Phthiraptera 1. Mallophags. Akademische Verlagsgesellschagt, Geest \& Portig. K.G. Leipzig. 5(3), 7b, 1-290.

Foster, M. S. (1969). The eggs of three species of Mallophaga and their significance in ecological studies. J. Parasitol., 55 (2), 453-456.

Gupta, N., Khan, V., Kumar, S., Saxena, S., Rashmi, A. and Saxena, A.K. (2008). Eggshell morphology of selected bird lice species (Phthiraptera: Amblycera, Ischnocera). Entomol. News (In Press)

Kalamarz, E. (1963). Badania nad biologia Mallophaga II. Krew jako pokarm larw piorojadow Menopon gallinae (L.) i Menacanthus stramineus (Nitzsch), oraz niektore inne obserwacje nad biologia tych gatunkow. Z. Nauk. W. S. R. Wolsz., 15, 253-260.

Kumar, A., Mitra, J.D. and Saxena, A.K. (1996). Hatching behaviour of goat biting louse, Bovicola caprae Gurlt (Phthiraptera: Ischnocera). Ad. Bios., 15(1), 25-32.

Kumar, P. and Somadder, S.K. (1974). Description and mechanism of hatching in three anopluran species. Indian J. Ent., 36(4), 355-358.

Kumar, S., Gupta, N. and Saxena, A.K. (2006). Egg laying patterns of phthirapteran ectoparasites infesting domestic hen, Gallus gallus domesticus. J. Parasit. Appl. Anim. Biol., 15 (1 \& 2), 11-15.

Marshall, A.G. (1981). The ecology of ectoparasitic insects. Academic Press, London. 459.

Martin, M. (1934). Life history and habits of the pigeons louse (Columbicola columbae [Linnaeus]). Can. Entomol., 66, 6-16. Murray MD 1957a: The distribution of the eggs of mammalian lice on their hosts. I. Description of the oviposition behaviour. Aust. J. Zool., 5, 13-18.

Murray, M.D. (1957b). The distribution of the eggs of mammalian lice on their hosts. II. Analysis of the oviposition behaviour of Damalinia ovis (L). Aust. J. Zool., 5, 19-29. 
Murray, M.D. (1957c). The distribution of the eggs of mammalian lice on their hosts. III. The distribution of the eggs of Damalinia ovis (L.) on the sheep. Aust. J. Zool., 5, 173-182.

Murray, M.D. (1957d). The distribution of the eggs of mammalian lice on their hosts. IV. The distribution of the eggs of Damalinia equi (Denny) and Haematopinus asini (L.) on the horse. Aust. J. Zool., 5, 183-187.

Nelson, B.C. (1971). Successful rearing of Colpocephalum turbinatum (Phthiraptera). Nature (London), 232, 255.

Nelson, B.C. and Murray, M,D. (1971). The distribution of Mallophaga on the domestic pigeon (Columba livia). Int. Parasitol., 1, 21-29.

Oniki, Y. (1999). The mating behaviour of Oxylipeurus variegates (Mallophaga : Lipeuridae). Garcia de Orta. Ser. Zool., 23 (1), 91-92.

Pfleger, K. (1929). Biologie der mallophagen. Diss. rer. nat. Dtsch. Univ. Prag., 304.

Richter, H.C. (1870). Eggs of bird's parasites. Hardwicks's Science gossip (London), 6, 123-133.

Rothschild, M. and Clay, T. (1952). Fleas, Flukes and Cuckoos: A study of bird parasites (Collins) London P. 305.

Saxena, A.K., Agarwal, G.P., Chandra, S. and Singh, O.P. (1985). Haematophagous nature of Trinoton querquedule (Phthiraptera: Amblycera). Angewandte Parasitol., 26, 205-208.

Saxena, A.K., Trivedi, M.C., Rawat, B.S. and Kumar, A. (1991). Bionomics of poultry louse, Lipeurus lawrensis tropicalis Peters (Phthiraptera: Ischnocera). J. Zool. Res., 4 (1 \& 2), 27-32.

Saxena, A.K., Trivedi, M.C., Kumar, A. and Rawat, B.S. (1993). Egg morphology of three amblyceran poultry lice (Insects, Phthiraptera). Rudolstandt. Nat. Hist. Schr., 5:65-68.

Saxena, A.K., Arya, S., Kumar, A., Singh, S.K. and Chauhan, S.C. (1994). SEM studies on the microtopography of eggs of poultry shaft louse, Menopon gallinae (Phthiraptera: Amblycera). Rivista di Parassitol., 11 (55): 275-281.

Saxena, A.K., Singh, S.K., Kumar, A., Surman and Badola, S. (2000). SEM studies on the microtopography of eggs of four pigeon lice (Phthiraptera: Insecta). Rivista di Parassitol., XVII (III), 351-358.

Saxena, A.K., Singh, S.K., Kumar, S. and Gupta, N. (2004). The influence of two environmental factors on the development of the eggs of two pigeon lice (Phthiraptera : Insecta). J. Parasit. Appl. Anim. Biol., 13 (1 \& 2): 39-44.

Schmutz, W. (1955). Zur konstruktionsmorphologie des mannlichen Geschelechtsapparates der Mallophaga. Zool. Jb. Anat., 74, 189-338.

Scott, M.T. (1952). Observations on the bionomics of the sheep body louse (Damalinia ovis). Aust. J. Agr. Res., 3: 60-67.

Seager, S.W., Schiller, E.L., Sladen, W.J.L. and Trpis, M. (1976). A Mallophaga, Trinotonanserinum; as a cyclodevelopmental vector for a heartworm parasite of a waterfowl. Science, 194:739-741.

Sikora, H. and Eichler, W. (1941). Uber kopulationseigentumlichkeiten der Mallophagen. Z. Morph. Okol., 38:80-84.
Singh, S.K. (1999). Ecology of phthirapterans infesting pigeons in Dehradun. Ph.D. Thesis, H.N.B Garhwal Univ., Srinagar (Garhwal), India, P. 150.

Singh, S.K., Kumar, A., Surman, Badola, S. and Saxena, A.K. (2000). Site preference of four pigeon lice (Phthiraptera, insecta) on the host body. Rivista di Parassitol., XVII (LXI) $-43: 341-349$.

Singh, S.K., Surman, Kumar. S, and Saxena, A.K. (2001). In vitro biology of a pigeon louse, Columbicola columbae (Phthiraptera : Ischnocera). Prof. V.N. Capoor Comm., 5456.

Snodgross, R.E. (1899). The anatomy of the Mallophaga. Occas. Pap. Calif. Acad. Sci., 6:145-224.

Stenram, H. (1956). The ecology of Columbicola columbae L (Mallophaga). Opscula Ent., 21 (2-3): 170-190.

Stockdale, H.J. and Raun, E.S. (1965). Biology of the chicken body louse, Menacanthus stramineus. Ann. Ent. Soc. Amer., 58(6): 802-805.

Surman, Singh, S.K., Saxena, A.K. and Kumar, A. (1998). Aspects of oviposition in the poultry shaft louse, Menopon gallinae (Phthiraptera : Amblycera). Rivista di Parassitol., XVII (LIX)-N. 3, 341-343.

Trivedi, M.C., Sharma, S., Rawat, B.S. and Saxena, A.K. (1990). Haematophagous nature of an amblyceran phthirapteran, Menacanthus cornutus Schommer, infesting poultry bird, Gallus domesticus L. in India. J. Appl. Entomol., 110:107-111.

Trivedi, M.C., Saxena, A.K. and Rawat, B.S. (1992). Incidence of Mallophaga on poultry in Dehradun (India). Angewandte. Parasitol., 33, 69-78.

Urban, E. and Zlotorzycka, J. (1981). Untersuchungen uber die lebensfahigkeit der Huhnermallophagen nach verlust ihres wirtes. Angew. Parasitol., 22:83-91.

Waterhouse, D.F. (1953). Studies on the digestion of wool by insects. IX. Some features of digestion in chewing lice (Mallophaga) from bird and mammalian hosts. Aust. J. Biol. Sci., 6(2), 257-275.

Waterston, J. (1926). On the crop contents of certain Mallophaga. Proc. Zool. Soc. London, 96:1017-1020.

Wigglesworth, V.B. (1932). The hatching organ or Lipeurus columbae Linn. (Mallophaga) with a notes on its phylogenetic significance. Parasitol., 24:365-367.

Williams, R.T. (1970). In vitro studies on the environmental biology of Goniodes colchici (Denny) (Mallophaga: Ischnocera) I. The effects of temperature and humidity on the bionomics of G. colchici. Aust. J. Zool., 18:379-389.

Wilson, F.H. (1933). A louse feeding on the blood of its hosts. Science, 77: 490.

Wilson, F.H. (1939). The life-cycle and bionomics of Lipeurus caponis (Linn). Ann. Entomol. Soc. Amer., 32:318-320.

Wobesser, G., Johnson, G.R. and Aconpanado, G. (1974). Stomotitis in a juvenile white pelican due to Piagetiella peralis (Mallophaga: Menoponidae). J. Wildlife Dis., 10:135-138. Zlotorzycka, J. and Danecki, J. (1969). O skutkach masowego pojawu wszolow (Mallophaga) z podgatunku Laemobothrion vultures danecki Zlotorzycka na orlosepie brodatym, Gypaetus barbatus (L.). Przegl. Zool., 13(4): 331-333. 